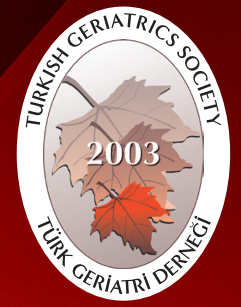

Turkish Journal of Geriatrics DOI: 10.31086/tigeri.2019.105 2019; 22(3): 295-304

- Duygu Illke YILDIRIM ${ }^{1}$ D - Ahmet Yıldırım² (D)

\title{
AN ASSESSMENT OF MOBILITY AND FALL BEHAVIOUR AMONG OLDER PATIENTS ADMITTED TO THE ORTHOPAEDIC OUTPATIENT CLINIC
}

\section{Abstract}

Introduction: Unintentional falls in older individuals can lead to fatal and non-fatal injuries. This study aimed to determine the risk factors for falls among elderly patients and to specify the timely safety measures that can be taken to prevent falls in the elderly population.

Materials and Method: This study is a descriptive, cross-sectional study of containing 178 older patients. Data for the study were collected with the sociodemographic questionnaire form, Rivermead Mobility Index and the Falls Behavioural Scale for the Older Persons.

Results: The mean age of the 178 patients in this study was $67.14 \pm 5.95$ years and $56.7 \%$ $(n=101)$ were female, $43.3 \%$ ( $n=77)$ were male. The patients who had a fear of falling and the patients who fell within the previous year; had a statistically significant level of low physical activity $(p=0.019, p=0.033)$. Males $(p=0.002)$, those aged 80 years and above, married patients, high school graduates, those on continuous medication and those who fell within the previous year had higher mean Falls Behavioural Scale scores $(p<0.001)$.

Conclusion: It may be beneficial to make the necessary arrangements that would not pose a risk in neighbourhoods populated by older adults; to assess their level of mobility when they show up for routine examination; to take adequate safety measures after determining their needs according to their mobility status and to organize the prescribed drugs according to falling probability.

Keywords: Aged; Orthopaedics; Accidental falls; Geriatrics; Movement

CORRESPONDANCE

\section{Ahmet YILDIRIM}

Selcuk University Faculty of Medicine,

Department of Orthopaedics and

Traumatology, Konya, Turkey.

Phone: +903322245023

e-mail: dr1907@gmail.com

Received: 05/03/2019

Accepted: $17 / 06 / 2019$

Konya Health Application and Research Center, University of Health Sciences, Department of Family Medicine, Konya, Turkey.

2 Selcuk University Faculty of Medicine, Department of Orthopaedics and Traumatology, Konya, Turkey.
ARAŞTIRMA

\section{ORTOPEDI POLIKLINIGĞINE BAŞVURAN YAŞLI HASTALARIN MOBILITE VE DÜŞME DAVRANIŞLARININ DEĞERLENDIRILMESI} $\ddot{O}_{z}$

Giriş: Yaşlı bireylerde istenmeyen düşmeler sonucu; ölümcül olan ve olmayan yaralanmalar meydana gelebilir. Bu çalışma yaşlı hastalarda düşme ile ilgili risk faktörlerini saptamak ve özellikle yaşlılarda düşmenin önlenmesi için zamanında alınabilecek güvenlik önlemlerini belirlemek için yapılmıştır.

Gereç ve Yöntem: :Tanımlayıcı, kesitsel bir çalışma olan araştırmamıza 178 yaşlı hasta dahil edilmiştir. Çalışma verileri; sosyodemografik anket formu, Rivermead Mobilite İndeksi ve Yaşıllar İ̧̧in Düşme Davranışları Ölçeği kullanılarak toplanmıştır.

Bulgular: Çalışmamıza katılan 178 hastanın yaş ortalaması $67.14 \pm 5.95$ olup; \%56.7'si kadın ( $n=101), \% 43.3$ 'ü erkekti ( $n=77)$. Düşme korkusu olan hastaların ve son 1 yıl içinde düşme öyküsü olan hastaların anlamlı derecede fiziksel aktivite yapmadığı belirlendi $(p=0.019, p=0.033)$. Yaşlı erkeklerin ( $p=0.002), 80$ yaş ve üzerinde olanların, evlilerin, lise mezunu olanların, sürekli ilaç kullanımı olanların, son bir yıl içinde düşenlerin; Yaşlılar İçin Düşme Davranışları Ölçeği'ne göre puan ortalamaları anlamlı derecede daha yüksektir $(p<0.001)$.

Sonuç: Yaşlı bireylerin yaşadıkları çevrede risk oluşturmayacak şekilde gerekli düzenlemelerin yapılması, periyodik muayeneye geldiklerinde mobilite düzeylerinin tespit edilmesi, ihtiyaçlarının mobilite durumuna göre belirlenerek yeterli güvenlik önlemlerinin alınması ve yaşlılara yazılan reçetelerin düşme intimalleri göz önüne alınarak yeniden düzenlenmesi erken dönemde düşmelerin önlenmesinde faydalı olabilir.

Anahtar sözcükkler: Yaşlı; Ortopedi; Düşmeler; Geriatri; Mobilite 


\section{INTRODUCTION}

In both Turkey and the rest of the world, the elderly population is growing and life expectancy is increasing with each passing day. The population aged 65 years or above has grown significantly relative to the total population in Turkey over the years. While the elderly population was $3.5 \%$ of the total population in 1940, it rose to $4.4 \%$ in 1970 , $7.5 \%$ in 2012 and $8.3 \%$ in 2016. Elderly population, which is defined as the population aged 65 years and above, is projected to increase to $10.2 \%$ in $2023,16.3 \%$ in $2040,22.6 \%$ in 2060 and $25.6 \%$ in 2080 (1).

Senescence is an inevitable phase that generally involves reduced perception and awareness, gradually deteriorating memory functions as well as physiological and mental changes that all humans will experience. According to the data of the Centre for Disease Control and Prevention (CDC), more than one-third of the adult population is at the age of 65 years and above (2). The data from the World Health Organization shows that 28\%$35 \%$ of the older individuals aged 65 years and above experience falls, and that the prevalence of falls increases each year with age $(3,4)$. These unintentional falls in older individuals can lead to non-fatal and fatal injuries. Nearly $20 \%-30 \%$ of falls are classified as moderate-to-severe injuries that require medical care and hospitalization (5). These injuries can have consequences including increased need for home healthcare services, loss of independence and increased rate of premature death in older adults (6). Risk factors include reduced muscle strength, visual impairment, diabetes, urinary incontinence, arthritis, dizziness, Alzheimer's disease, depression, orthostatic hypotension, cognitive impairment, polypharmacy, persistent pain and some of the prescribed drugs (2). Studies have shown that psychological stress also has a significant effect on falls among the elderly $(7,8)$. It was found that, following recurrent falls, older adults tended to develop such a fear of falling that it led to loss of physical activity, which in turn led to a higher risk of falling (9). Studies have also shown that nurses, physicians and therapists could help reduce the rate of falls by $20 \%-30 \%$ when they work together and help the patients take the necessary precautions (10).

In 2010, approximately 2.3 million older adults with non-fatal fall-related injuries were treated in emergency departments. The direct medical cost of falls was 30 billion USD in 2010, and it is projected that annual direct and indirect costs of fall-related injuries will rise to 67.7 billion USD by 2020 (11). In another study, it was found that falls made a significant contribution to the costs, and that this was especially valid for hospitalisation periods of more than 8 days (12). Considering the economic burden associated with falls, it would be highly beneficial to take the necessary precautions and make interventions to minimise the risk of falling.

This study aimed to determine the risk factors for falls among elderly patients and to specify the timely safety measures that can be taken to prevent falls in the elderly population.

\section{MATERIALS AND METHOD}

This study is a descriptive, cross-sectional study. The study group consisted of 178 older patients who were admitted to the Orthopaedics and Traumatology Outpatient Clinic between 1 November 2018 and 1 December 2018. All elderly patients who were admitted to the orthopaedic outpatient clinic between the specified dates, who volunteered to participate in the study, who were able to communicate and who were not diagnosed with dementia were included in this study. All the elderly patients volunteered to participate in the study with provided informed consent. Data for the study were collected with the sociodemographic questionnaire form, Rivermead Mobility Index (RMI) and the Falls Behavioural Scale (FaB) for the Older Persons. The approval for this study was obtained from the Non-Interventional Clinical 
Research Ethics Committee of Selcuk University Faculty of Medicine with its decision number 20, dated 24.10.2018.

Socio-demographic Questionnaire Form: The questionnaire included socio-demographic characteristics of the patients (gender, age, body mass index, marital status, education status, regular physical activity status) and information about use of continous medication.

Rivermead Mobility Index (RMI): RMI was developed by Collen et al. (13), and the validity and reliability study of the index's Turkish version was performed by Akın and Emiroğlu (14). RMI is a unidimensional index that includes the basic mobility activities, and it was prepared to assess the mobility status of older patients (13). This index comprises 14 questions, 13 of which are patient self-reported items to measure mobility. Only Item 5 is filled out by the interviewer based on direct observations. Each question in the index receives a score of either 0 or 1 . After scoring, the lowest possible score on this index is ' $O$ ', while the highest possible score is ' 15 '. A total score of 15 indicates that there are no mobility problems, whereas total scores of 14 and lower indicate that there is a mobility problem (14).

Falls Behavioural Scale for the Older Person (FaB): The scale was developed in 2003 by Clemson, Cuming and Heard (15), and the validity and reliability study for the Turkish version of the index was performed by Uymaz and Nahcivan in 2013 (16). This scale was developed to reveal the awareness and behaviours of older adults in terms of protecting themselves from potential falls in their daily lives. The scale consists of 30 items and has 10 sub-dimensions. These subdimensions consist of cognitive adaptation, protective mobility, avoidance, awareness, pace, practical strategies, changes in the activity plan, being observant, changes in level and getting to the phone. Each sub-dimension is scored from 1 to 4 . The lowest score from the scale is ' 1 ', while the highest score is ' 4 ', such that the score ranges between 1 and 4. Except for Items 7, 8, 9, 10, 19 and 23 on the scale, responses to the other items are scored as follows: 'never' 1 point, 'sometimes' 2 points, 'often' 3 points and 'always' 4 points. The score for each sub-dimension is individually calculated by dividing the total score of all subdimensions by the number of items. High scores show the preventive and safe behaviours of patients in relation to falls, whereas low scores show risky patient behaviour in relation to the same (5).

\section{Statistical analysis}

Statistical analyses were performed using the Statistical Package for the Social Science version 22.0 software. In data analysis, descriptive statistics were provided with frequency (n), percentage (\%), mean \pm standard deviation, and min-max values. Regarding statistical significance, non-parametric Mann-Whitney $U$ test was used to compare the data according to continuous variables, KruskalWallis $\mathrm{H}$ test was used to compare more than two groups and Bonferroni Test was used to determine between which groups there was a difference. Normal distribution of the data was analysed using the Kolmogorov-Smirnov test of normality. A $p$ value $<0.05$ was accepted as statistically significant.

\section{RESULTS}

Of the patients, $56.7 \%(n=101)$ were female and $43.3 \%(n=77)$ were male. The mean age of the 178 patients who were enrolled in our study was 67.14 \pm 5.95 years (min: 60, max: 83). Furthermore, $69.1 \%(n=123)$ of the patients were married, while $30.9 \%(n=55)$ of the patients were either single or widowed. Among the patients, $48.3 \%(n=86)$ were primary school graduates and $24.7 \%(n=44)$ were high school graduates. It was observed that $64.6 \%(n=115)$ of the patients were on continuous medication, whereas $35.4 \%(n=63)$ were not. The mean body mass index (BMI) of the patients was $31.18 \pm 4.58$ (min: 23.00, max: 46.10) kg/m2. Regular physical activity; regular, planned and repeated 
physical activities aimed at the protection or development of one or more components of physical fitness. Also, $69.61 \% \quad(n=123)$ of the patients did not regularly engage in physical activity (Table 1).

Of the patients, $58.4 \%$ stated that they experienced a fear of falling, whereas $41.6 \%$ said that they never felt such a fear. In addition, 51.1\% of the participants said that they fell at least once, whereas $48.9 \%$ said that they did not fall within the recent year. A total of 91 patients said that they fell at least once; $32.6 \%$ of those who fell within the recent year stated that they fell three times or more, whereas $15.2 \%$ and $3.4 \%$ stated that they fell twice and once, respectively (Table 2 ).

The mean RMI score of the older patients was 9.31 \pm 1.72 . The mean $\mathrm{FaB}$ score of the patients was $2.71 \pm 0.21$. Analysing the sub-dimensions of the scale, the highest mean score belonged to 'being observant' with $2.94 \pm 0.86$ and 'awareness' with $2.94 \pm 0.27$, whereas the lowest mean score belonged to 'change in the activity plan' with $1.78 \pm 0.55$ (Table 3).

The mean RMI scores of the elderly patients who were admitted to the orthopaedic outpatient clinic exhibited a statistically significant difference according to gender, with females having a higher mean score in comparison to males $(p=0.009)$. The mean RMI scores of the patients also exhibited a statistically significant difference according to age $(p<0.001)$, with such a difference being observed between the 60-65-year age group and the 6679 -year age group $(p<0.001)$, and also between the 60-65-year age group and the group aged 80 years and above $(p<0.001)$. A statistically significant difference was noted between the mean RMI scores according to marital status, and single and widowed patients had a higher mean score in comparison to the married patients $(p<0.001)$. The mean RMI scores exhibited a statistically significant difference according to education status, and such difference was observed between literate patients and high school graduates $(p=0.03)$, and between primary school graduates and high school graduates $(p<0.001)$. A statistically significant difference was noted between the mean RMI scores according to the continuous use of medication, with patients who were not on continuous medication having a higher mean score than those on continuous medication $(p<0.001)$. The mean RMI scores exhibited a statistically significant difference according to the fear of falling, wherein patients who did not experience a fear of falling had a higher mean score than those who experienced this fear $(p<0.001)$. The mean RMI scores exhibited a statistically significant difference according to the incidence of falls within the last year, with patients who did not fall within the previous year having a higher mean score than those who did $(p=0.019)$ (Table 4).

A statistically significant difference was noted between mean RMI scores according to the BMI groups, with such a difference being observed between the group with a BMI of $18.5-24.9 \mathrm{~kg} /$ $\mathrm{m} 2$ and the group with a BMI of $25.0-29.9 \mathrm{~kg} /$ $\mathrm{m} 2$, and also between the group with a BMI of $18.5-24.9 \mathrm{~kg} / \mathrm{m} 2$ and the group with $\mathrm{BMI} \geq 30 \mathrm{~kg} /$ $m 2(p=0.005)$. Considering the mean FaB score of the older patients, it was found that males $(p=0.002)$, those aged 80 years and above, married patients, high school graduates, those on continuous medication and those who fell within the previous year had higher mean FaB scores, and the difference between the groups was also statistically significant $(p<0.001)$ (Table 4).

\section{DISCUSSION}

This study aimed to evaluate the mobility and fall behaviour of elderly patients who were admitted to the orthopaedic outpatient clinic and found that $51.2 \%$ of the older patients fell within the previous year, and that $32.6 \%$ of these patients had fallen three times or more. According to the WHO data, the prevalence of falls among older adults is 
Table 1. Sociodemographic characteristics of the patients.

\begin{tabular}{|c|c|c|c|}
\hline Variable & Category & $\mathrm{n}$ & $\%$ \\
\hline \multirow{2}{*}{ Gender } & Female & 101 & 56.7 \\
\hline & Male & 77 & 43.3 \\
\hline \multicolumn{4}{|c|}{ Age, Mean $\pm S D(\min -m a x) 67.14 \pm 5.95(60-83)$} \\
\hline \multirow{3}{*}{ Age groups } & Between 60-65 & 102 & 57.3 \\
\hline & Between 66-79 & 64 & 36.0 \\
\hline & 80 and above & 12 & 6.7 \\
\hline \multirow{2}{*}{ Marital status } & Married & 123 & 69.1 \\
\hline & Single+Widowed & 55 & 30.9 \\
\hline \multirow{4}{*}{ Education status } & Literate & 26 & 14.6 \\
\hline & Primary School & 86 & 48.3 \\
\hline & High School & 44 & 24.7 \\
\hline & University and higher & 22 & 12.4 \\
\hline \multirow{2}{*}{ Continuous medication } & Yes & 115 & 64.6 \\
\hline & No & 63 & 35.4 \\
\hline \multicolumn{4}{|c|}{$\mathrm{BMI}, \mathrm{mean} \pm \mathrm{SD}(\min -\max ) 31.18 \pm 4.58(23.00-46.10)$} \\
\hline \multirow{3}{*}{ BMl groups } & $18.5-24.9$ & 7 & 3.9 \\
\hline & $25.0-29.9$ & 65 & 36.5 \\
\hline & $\geq 30$ & 106 & 59.6 \\
\hline Regular physical & Yes & 55 & 30.9 \\
\hline Activity status & No & 123 & 69.1 \\
\hline Total & & 178 & 100.0 \\
\hline
\end{tabular}

Mean \pm SD: Mean \pm standard deviation, BMI: Body mass index

28\%-35\% for those living in their home, and even higher (i.e. 30\%-50\%) for those living in a nursing home $(3,17)$. The prevalence we found in our study was higher than that reported in China (18\%) (18), Sweden (19.1\%) (19) and Nigeria (23\%) (20), and lower than that reported in Egypt (60.3\%) (21). This difference may stem from many behavioural, environmental, psychological and biological factors. Another problem that affects elderly adults is the fear of falling. In our study, $58.4 \%$ of the older adults stated that they experience a fear of falling. Other studies reported that $66 \%$ of older women in Netherlands (22), $84 \%$ of older women in Korea (23) and $35 \%$ of older women in the United 
Table 2. Distribution of older patients according to their characteristics concerning the history of falls $(n=178)$.

\begin{tabular}{|c|c|c|c|}
\hline Variable & Category & $\mathrm{n}$ & $\%$ \\
\hline \multirow{2}{*}{ Experienced fear of falling } & Yes & 104 & 58.4 \\
\hline & No & 74 & 41.6 \\
\hline \multirow{2}{*}{ Fell within the recent year } & Yes & 91 & 51.1 \\
\hline & No & 87 & 48.9 \\
\hline \multirow{3}{*}{ Number of falls ${ }^{a}(n=91)$} & Once & 6 & 3.4 \\
\hline & Twice & 27 & 15.2 \\
\hline & 3 times or more & 58 & 32.6 \\
\hline
\end{tabular}

ancludes the patients who reported that they fell at least once within the recent year.

States (24) experience a fear of falling. The varying prevalence of fear of falling in each society could be due to the differences in cultural structure, history of falls, age distribution and so on.

The falls and the fear of falling experienced by older adults are essentially due to their mobility problems. We observed the mobility status of patients using RMI. Considering the fact that older patients who receive a score of 14 or less have mobility problems, we found that there were mobility problems as the mean RMI score of the patients who participated in our study was $9.31 \pm 1.72$. According to another study, the mean RMI score of 124 older adults living in a nursing home was $10.27 \pm 4.25$, indicating that they had mobility problems (25). Scimia et al. measured the RMI scores of 108 patients aged 80 years and above upon admission (RMI1) and after a daily 6-minute walk test (RMI2), and found a mean RMI1 score of $8.5 \pm 3.4$ and a mean RMI2 score of $13.1 \pm 2.9$, thus observing that the RMI score was positively affected by cardiac rehabilitation (26). This indicates that mobility-related problems increase with advancing age.

There was a statistically significant relationship between the mean RMI scores and gender, age, marital status, education status, continuous use of medication, the fear of falling, a history of fall within the previous year and BMI (Table 4). Wu et al. reported in their study conducted on 671 elderly adults that female gender, age-related bone weakness and polypharmacy were associated with increased risk of falling (27). In a study by Okuyan and Bilgili, a statistically significant relationship was observed between gender, education status, age, the fear of falling, physical activity status and mean RMI scores (25). Although the prevalence of mobility problems is reportedly higher in females according to the literature, we found that the prevalence of mobility problems was significantly higher in males. In our study, we also found a significant correlation between the continuous use of medication, advanced age and mean RMI scores, which is consistent with the literature.

We did not find a significant relationship between physical activity status and RMI, while older patients who had a fear of falling and fell within the previous year did not have a statistically significant level of physical activity. Lim et al. conducted a study on 438 females aged 65 years and above, and reported that physical inactivity was an important risk factor that could be accountable for recurrent falls (28). According to the literature, 
Table 3. Mean RMI and FaB Scores.

\begin{tabular}{|c|c|c|c|}
\hline Scales and sub-dimensions & Cronbach's alfa & Mean \pm SD & Min-Max \\
\hline RMI & .81 & $9.31 \pm 1.72$ & $2-15$ \\
\hline \multicolumn{4}{|l|}{ FaB Sub-dimensions } \\
\hline Cognitive adaptation & .70 & $2.85 \pm 0.26$ & 2.5-3.1 \\
\hline Protective mobility & .63 & $2.60 \pm 0.61$ & $1.8-3.2$ \\
\hline Avoidance & .56 & $2.76 \pm 0.27$ & $2-3$ \\
\hline Awareness & .53 & $2.94 \pm 0.27$ & 2.2-3.2 \\
\hline Pace & .60 & $2.85 \pm 0.46$ & $2-3.5$ \\
\hline Practical strategies & .52 & $2.56 \pm 0.28$ & $2-3$ \\
\hline Changes in the activity plan & - & $1.78 \pm 0.55$ & $1-3$ \\
\hline Being observant & - & $2.94 \pm 0.86$ & $1-4$ \\
\hline Changes in level & .61 & $2.31 \pm 0.24$ & $2-2.5$ \\
\hline Getting to the phone & - & $2.79 \pm 0.40$ & $2-3$ \\
\hline FaB total & .85 & $2.71 \pm 0.21$ & $2.4-3$ \\
\hline
\end{tabular}

RMI: Rivermead Mobility Index; FaB: Falls Behavioural Scale for the Older Person; Mean \pm SD: Mean \pm standard deviation.

a physically inactive life is considered to be a risk factor for falls $(25,28)$. On the basis of all these results, we may say that older patients who have a history of falling also have a lower level of physical activity due to their fear of falling.

In our study, the mean FaB score, which is a measure of protective mobility practised by older adults to protect themselves from potential falls throughout the day, was $2.71 \pm 0.21$. Considering that the lowest score is 1 and that the highest score is 4 on this scale, it can be stated that elderly patients engage in a moderate level of protective behaviour to protect themselves from falls. Okuyan and Bilgili found a mean $\mathrm{FaB}$ score of $2.99 \pm 0.56$ (25). These results imply that elderly adults do not have sufficient falls awareness. The mean scores of all sub-parameters of the scale were lower than 3 in our study (Table 3). Okuyan and Bilgili found the mean scores to be higher than 3 in the sub- dimensions of cognitive adaptation, avoidance, awareness, pace, changes in the activity plan and changes in level, and observed the older adults had a better protection from falls (25).

The fact that the elderly population is growing at a fast pace puts great responsibilities on physicians, especially on primary care physicians, with regard to falls among the elderly. Our study showed that the frequency of falls was high in elderly adults who are admitted to the orthopaedic outpatient clinic. In daily orthopaedic practice; clinicians always focus to stop pain and prescribes narcotics, pregabalin, gabapentine or tizanidine so often for geriatric population with the diagnoses "spinal stenosis, gonarthrosis, coxarthrosis and the other degenerative and rheumotologic problems ". These prescribes turn a continous usage at the family medicine clinics for geriatric population. The adverse affects of these drugs as causes of 
Table 4. Comparison of mean RMI and FaB scores according to several patient characteristics.

\begin{tabular}{|c|c|c|c|c|c|c|c|}
\hline & & & \multicolumn{3}{|c|}{ RMI } & \multicolumn{2}{|c|}{$\mathrm{FaB}$} \\
\hline \multirow[t]{2}{*}{ Variable } & Category & $\mathrm{n}$ & Mean \pm SD & \multicolumn{2}{|c|}{$x 2$} & Mean \pm SD & $\times 2$ \\
\hline & & & & & $f / z$ & & $f / z$ \\
\hline \multirow{2}{*}{ Gender ${ }^{b}$} & Female & 101 & $9.57 \pm 1.82$ & \multirow{2}{*}{\multicolumn{2}{|c|}{$2.6120 .009^{*}$}} & $2.62 \pm 0.20$ & \multirow{2}{*}{$3.0710 .002^{\star}$} \\
\hline & Male & 77 & $9.15 \pm 1.47$ & & & $2.79 \pm 0.20$ & \\
\hline \multirow{3}{*}{ Age groups ${ }^{a}$} & Between 60-65 & 102 & $9.83 \pm 1.99$ & \multirow{3}{*}{33.172} & \multirow{3}{*}{$<0.001^{*}$} & $2.59 \pm 0.15$ & \multirow{3}{*}{$52.679<0.001^{\star}$} \\
\hline & Between 66-79 & 64 & $8.77 \pm 0.79$ & & & $2.82 \pm 0.22$ & \\
\hline & $80+$ & 12 & $8.60 \pm 0.54$ & & & $2.95 \pm 0.03$ & \\
\hline Marital & Married & 123 & $9.28 \pm 1.87$ & \multirow{2}{*}{\multicolumn{2}{|c|}{$5.220<0.001^{*}$}} & $2.79 \pm 0.19$ & \multirow{2}{*}{$8.730<0.001^{\star}$} \\
\hline status $^{b}$ & Single+Widowed & 55 & $9.60 \pm 1.22$ & & & $2.49 \pm 0.03$ & \\
\hline \multirow{4}{*}{$\begin{array}{l}\text { Education } \\
\text { status }^{\text {a }}\end{array}$} & Literate & 26 & $9.00 \pm 0.01$ & \multirow{4}{*}{\multicolumn{2}{|c|}{$48.369<0.001^{*}$}} & $3.00 \pm 0.01$ & \multirow{4}{*}{$82.400<0.001^{\star}$} \\
\hline & Primary School & 86 & $9.18 \pm 1.39$ & & & $2.66 \pm 0.18$ & \\
\hline & High School & 44 & $9.81 \pm 2.46$ & & & $2.70 \pm 0.23$ & \\
\hline & $\begin{array}{r}\text { University and } \\
\text { higher }\end{array}$ & 22 & $9.61 \pm 1.38$ & & & $2.50 \pm 0.01$ & \\
\hline \multirow{2}{*}{$\begin{array}{l}\text { Continuous } \\
\text { use of } \\
\text { medication }\end{array}$} & Yes & 115 & $9.06 \pm 1.35$ & \multirow{2}{*}{\multicolumn{2}{|c|}{$6.660<0.001 *$}} & $2.81 \pm 0.19$ & \multirow{2}{*}{$8.757<0.001 *$} \\
\hline & No & 63 & $9.92 \pm 2.03$ & & & $2.50 \pm 0.04$ & \\
\hline \multirow{2}{*}{$\begin{array}{l}\text { Experienced } \\
\text { fear of falling }\end{array}$} & Yes & 104 & $9.10 \pm 0.90$ & \multirow{2}{*}{\multicolumn{2}{|c|}{$3.587<0.001^{*}$}} & $2.71 \pm 0.23$ & \multirow{2}{*}{0.7090 .479} \\
\hline & No & 74 & $9.80 \pm 2.35$ & & & $2.67 \pm 0.19$ & \\
\hline \multirow{2}{*}{$\begin{array}{l}\text { Fell within the } \\
\text { previous year }\end{array}$} & Yes & 91 & $9.20 \pm 1.43$ & \multirow{2}{*}{\multicolumn{2}{|c|}{$2.3510 .019^{*}$}} & $2.79 \pm 0.21$ & \multirow{2}{*}{$4.403<0.001^{\star}$} \\
\hline & No & 87 & $9.62 \pm 1.94$ & & & $2.57 \pm 0.14$ & \\
\hline \multirow{3}{*}{ BMl groups ${ }^{a}$} & $18.5-24.9$ & 7 & $12.50 \pm 2.34$ & \multirow{3}{*}{\multicolumn{2}{|c|}{$10.4440 .005^{\star}$}} & $2.51 \pm 0.06$ & \multirow{3}{*}{3.5970 .166} \\
\hline & $25.0-29.9$ & 65 & $9.74 \pm 1.54$ & & & $2.72 \pm 0.21$ & \\
\hline & $\geq 30$ & 106 & $8.92 \pm 1.31$ & & & $2.70 \pm 0.22$ & \\
\hline
\end{tabular}

* = represents significance at $\mathrm{p}<0.05$ level; a: Kruskal-Wallis $\mathrm{H}$ test was performed; $\mathrm{b}$ : Mann-Whitney $\mathrm{U}$ test was performed.

suddenly falls are known in the literature with the high evidence studies and we try to highlighten this point in the conclusion part. Clinicians may prefer to solve the main reasons of pain, instead of just killing the pain only. The majority of older adults experienced a fear of falling and refrained from physical activity. According to our study, factors such as the male gender, advanced age, being married, high BMI, continuous use of medication, a fear of falling and having a history of falls in the previous year negatively affected the mobility level, and constituted a risk for falling. Physicians who treat and perform follow-ups for elderly patients should primarily provide trainings on safe/ protective and risky behaviours for their patients in order to prevent falls. Older adults should also be 
encouraged to engage in regular physical activity. In the short-term, it may be beneficial to make the necessary arrangements that would not pose a risk in neighbourhoods populated by older adults; to assess their level of mobility when they show up

\section{REFERENCES}

1. TurkStat, Elderly Statistics, 2018, Turkish Statistical Institute. [Internet] Available from: http://www.tuik. gov.tr/PreHaberBultenleri.do?id=30567. Accessed: 16.2.2019.

2. CDC. Costs of falls among older adults 2015. [Internet] Available from: http://www.cdc.gov/ HomeandRecreationalSafety/Falls/. Accessed: 16.2.2019.

3. World Health Organization. [Internet] Available from: https://www.who.int/ageing/publications/Falls_ prevention7March.pdf. Accessed: 16.2.2019.

4. Demirdel S, Şahinoğlu D, Karahan S, Demirdel E, Topuz S. Development of the physical activity barriers scale for elderly individuals. Turkish Journal of Geriatrics 2018;21 (4):607-616. doi: 10.31086/ tjgeri.2018.68.

5. Sterling DA, O'connor JA, Bonadies J. Geriatric falls: injury severity is high and disproportionate to mechanism. J Trauma Acute Care Surg 2001;50(1):1169. (PMID: 11231681).

6. Alexander BH, Rivara FP, Wolf ME. The cost and frequency of hospitalization for fall-related injuries in older adults. Am J Public Health 1992;82(7):1020-3. (PMID: 1609903).

7. Makizako $H$, Shimada $H$, Doi $T$, et al. The combined status of physical performance and depressive symptoms is strongly associated with a history of falling in community-dwelling elderly: cross-sectional findings from the Obu Study of Health Promotion for the Elderly (OSHPE). Arch Gerontol Geriatr 2014;58(3):327-31. (PMID: 24525136).

8. Quach L, Yang FM, Berry SD, et al. Depression, antidepressants, and falls among communitydwelling elderly people: the Mobilize Boston study. J Gerontol A Biol Sci Med Sci 2013;68(12):1575-81. (PMID: 23817088).

9. Han BH, Ferris R, Blaum C. Exploring ethnic and racial differences in falls among older adults. J Community Health 2014;39(6):1241-7. (PMID: 24585104).

10. Pearce L. Preventing falls in hospital. Nurs Stand for routine examination; to take adequate safety measures after determining their needs according to their mobility status and to reduce the number of unnecessary drugs prescribed to older adults.

\section{7;31(19):15. (PMID: 28094627).}

11. Nakagawa HB, Ferraresi JR, Prata MG, Scheicher ME. Postural balance and functional independence of elderly people according to gender and age: crosssectional study. Sao Paulo Med J 2017;135(3):260-5. (PMID:28746661).

12. Morello R, Barker A, Watts J, et al. The extra resource burden of in-hospital falls: a cost of falls study. Med J Australia 2015;203(9):367. e1-e8. (PMID: 26510807).

13. Collen, F. M, Wade DT, Robb GF, Bradshaw CM. The Rivermead mobility index: a further development of the Rivermead motor assessment. International disability studies 1991;13(2): 50-54. (PMID: 1836787).

14. Akin B, Emiroglu ON. The validity and reliability of the Turkish version of Rivermead Mobility Index in the elderly. Turkish Journal of Geriatrics 2007;10(3): 124130.

15. Clemson L, Cumming RG, Heard R. The development of an assessment to evaluate behavioral factors associated with falling. The American journal of occupational therapy 2003;57(4): 380-388. (PMID: 12911079).

16. Uymaz PE, Nahcivan N. Yaşlılar İçin Düşme Davranışları Ölçeği'nin Geçerlik ve Güvenirliği. Florence Nightingale Hemşirelik Dergisi 2013;21(1): 22-32.

17. Da Costa EM, Pepersack T, Godin I, Bantuelle M, Petit $B$, Levêque A. Fear of falling and associated activity restriction in older people. results of a cross-sectional study conducted in a Belgian town. Arch Public Health 2012;70(1):1. (PMID: 22958732).

18. Pu-Lin $Y$, Zhao-Hui $Q$, Jing $S$, et al. Prevalence and related factors of falls among the elderly in an urban community of Beijing. Biomed Environ Sci 2009;22(3):179-87. (PMID: 19725459).

19. Stenhagen M, Ekström H, Nordell E, Elmståhl S. Falls in the general elderly population: a 3-and 6-year prospective study of risk factors using data from the longitudinal population study 'Good ageing in Skane'. BMC Geriatr 2013;13(1):81. (PMID: 23919320). 
20. Bekibele C, Gureje O. Fall incidence in a population of elderly persons in Nigeria. Gerontology 2010;56(3):278-83. (PMID: 19738364).

21. Kamel MH, Abdulmajeed AA, Ismail SE-S. Risk factors of falls among elderly living in Urban Suez-Egypt. Pan Afr Med J 2013;14(1). (PMID: 23504298).

22. Zijlstra G, Van Haastregt J, Van Eijk JTM, van Rossum E, Stalenhoef PA, Kempen GI. Prevalence and correlates of fear of falling, and associated avoidance of activity in the general population of communityliving older people. Age Ageing 2007;36(3):304-9. (PMID: 17379605).

23. Kim S, So W-Y. Prevalence and correlates of fear of falling in Korean community-dwelling elderly subjects. Exp Gerontol 2013;48(11):1323-8. (PMID: 24001938).

24. Arfken CL, Lach HW, Birge SJ, Miller JP. The prevalence and correlates of fear of falling in elderly persons living in the community. Am J Public Health
1994;84(4):565-70. (PMID: 8154557).

25. Okuyan B, Bilgili N. Mobility and fall behaviors in the elderly: a nursing home study. J Edu Res Nurs 2018;15(1):1-8. (in Turkish). doi:10.5222/ HEAD.2018.001.

26. Scimia F, Casadei I, Cerquetani E, et al. Functional evaluation of ultra-octogenarian patients undergoing cardiac rehabilitation: correlation between six minute walking test and rivermead mobility index. Monaldi Arch Chest Dis 2015;74(4). (PMID: 21337805).

27. Wu TY, Chie WC, Yang RS, et al. Factors associated with falls among community-dwelling older people in Taiwan. Ann Acad Med Singap 2013;42(7):320-7. (PMID: 23949261).

28. Lim YM, Sung MH. Home environmental and healthrelated factors among home fallers and recurrent fallers in community dwelling older Korean women. Int J Nurs Pract 2012;18(5):481-8. (PMID: 23009377). 